\title{
Maintaining Karonese Ecolexicon through Traditional Game Cengkah-cengkah
}

\author{
Bahagia Tarigan, Rudy Sofyan* \\ Linguistics Department, University of Sumatera Utara, Medan, Indonesia \\ Corresponding Author: Rudy Sofyan, E-mail: rudy@usu.ac.id
}

\section{ARTICLE INFO}

Article history

Received: February 02, 2018

Accepted: April 18, 2018

Published: July 01, 2018

Volume: 7 Issue: 4

Advance access: May 2018

Conflicts of interest: None

Funding: None

\begin{abstract}
A language and its environment are so dependent one another that maintaining a language also means maintaining its environment. One of the purposes of studying a language and its environment is to maintain the lexicon associated with the ecological environment, known as ecolexicon. This paper aims at maintaining Karonese ecolexicon through cengkah-cengkah, one of the Karonese traditional games in Lau Kambing and Turangi, the villages located in Salapian Sub-District, Langkat Regency, North Sumatra, Indonesia. The study was conducted based on ecolinguistic and sociolinguistic perspectives. The data were the ecolexicon used in the Karonese traditional game cengkah-cengkah (both its old and new version). The data were collected using interview and document techniques. Based on the data analysis, it was found that the new version of Karonese traditional game cengkah-cengkah inserted more ecolexical items related to flora, cardinal points and land matters. Besides, most of the ecolexical items inserted in this game were the endangered ecolexicon that needed to be maintained. Based on the research findings, it is concluded that traditional games can serve as a good alternative way of language maintenance. Therefore, it is suggested to other researchers to do more studies on language maintenance involving traditional games from other regions.
\end{abstract}

Key words: Cengkah-cengkah, Ecolexicon, Karonese traditional game, Language maintenance

\section{INTRODUCTION}

Most of studies on language maintenance focus on minority languages (cf. Cardoso 2014; David, Cavallaro and Coluzzi 2009; Fang 2017; Rosa 2013) which are categorized as endangered languages (cf. Sallabank 2010; Wamalwa and Oluoch 2013), and some focus on a language spoken by a minority group living in a language-dominant society (cf. Hult 2004; Zhang 2004). This paper, however, talks about maintaining a Karonese language which continues to be spoken in Lau Kambing and Turangi, two among other villages located at Salapian Sub-District, Langkat Regency, North Sumatra Province, Indonesia (see Figure 1). At glance, it is somehow surprising to talk about maintaining a "safe" language. However, despite its safe language status, some of its lexicon has been endangered, particularly ecology-related lexicon known as ecolexicon (the term proposed by Faber, León-Araúz and Reimerink 2014, 2016). In addition to Karonese language, people in these two villages also speak Javanese language, another local language, and bahasa Indonesia, the national language which may influence the existence of Karonese ecolexicon in these two villages. This indicates that these two villages are not only composed of multilingual society but also multiethnic society.

Nevertheless, the status of several types of lexicon, e.g. ecolexicon, in these two villages is threatened due to several factors. Tarigan, Setia, Widayati and Mbete (2016, p. 14) note that Karonese language spoken in Salapian Sub-District has experienced ecological changes significantly due to several factors. First, the arrival of new comers with different languages certainly influences the Karonese speech community in Salapian Sub-District. Second, the electronic devices together with their own registers coming to this sub-district introduce new lexicons that must be adopted by the local people due to the absence of their equivalents in the local language. Third, the rapid growth of electronic games replaces the traditional games of Karonese people that used to be played by utilizing the objects around their environment as the game tools. Fourth, the school policy requiring children in the kindergartens to communicate in bahasa Indonesia affects the children's acquisition of the Karonese language. Those factors will seriously kill the ecolexicon of Karonese language in the villages at Salapian Sub-District, particularly in Lau Kambing and Turangi, or may eventually kill other types of lexicon of Karonese language in these two villages, if there is no serious effort to maintain it.

One of the efforts to maintain Karonese ecolexicon can be realized in revitalizing Karonese traditional games in these two villages, such as "cengkah-cengkah" game which is discussed in this paper. The use of the term "revitalization" in 


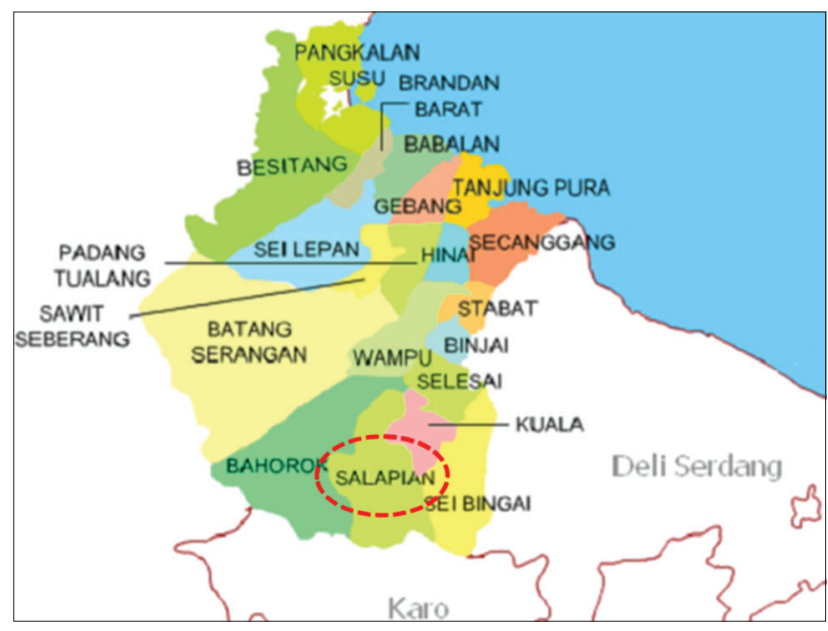

Figure 1. The sub-districts in Langkat Regency

this context refers to an effort to make the cengkah-cengkah game gain its popularity back. According to Wilczkiewicz and Wilkosz-Mamcarczyk (2015, p. 72), revitalization can be defined as a many-sided effort including revalorization, restoration, reconstruction, modernization, and actions aimed at revival of a building, district or a town devastated in various aspects, also economic and social aspects. This idea suggests that revitalization can be used in various meaning depending on the discipline (architecture, social sciences, economics, laws, etc.). In relation to Wilczkiewicz and Wilkosz-Mamcarczyk's definition, the revitalization in this paper is related to efforts of maintaining Karonese ecolexicon through cengkah-cengkah game. In addition, doing this research also shows one the 10 efforts of language maintenance proposed by Kirkness (2001) that includes: (1) banking our languages, (2) raising the consciousness level of our people, (3) mobilizing our resources, (4) providing training and certification, (5) developing a comprehensive and appropriate curriculum, (6) engaging in meaningful research, (7) informing public opinion, (8) eliminating artificial boundaries, (9) pressing for local language legislation, and (10) working together. Therefore, the larger the number of studies on a certain language is conducted the more likely that language will be maintained.

"Cengkah-cengkah" is a Karonese traditional game used to be played by children at school or at home. In most of the parts in Indonesia, cengkah-cengkah is called engklek (hopscotch). Revitalizing this game has been done by Tarigan and Sofyan (2017) by inserting more ecolexicon in the game. The arena of their new version of cengkah-cengkah game, called a bongbong more tree-shaped hopscotch, is shown in Figure 2.

In relation to this new version of cengkah-cengkah, the following research questions were formulated:

1. What are the Karonese ecolexical items inserted into the new version of cengkah-cengkah game played in Lau Kambing and Turangi?

2. How do such inserted ecolexical items contribute to maintain Karonese ecolexicon spoken in Lau Kambing and Turangi?

3. How does this new version of cengkah-cengkah game contribute to the ecosystem in Lau Kambing and Turangi?

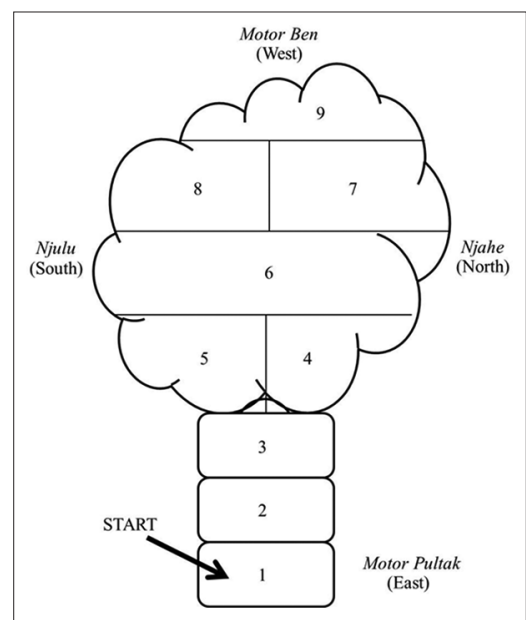

Figure 2. Cengkah-cengkah game arena (bongbong more tree-shaped hopscotch) (Tarigan and Sofyan 2017, p. 2)

\section{LITERATURE REVIEW}

\section{Ecolinguistics Approach}

Ecolinguistics, a branch of linguistics studying the interaction between language and its environment (Haugen 1972, p. 325), combines environment, conservation, interaction and language system (Fill 2001, p. 44) in its analysis. In addition, studying ecolinguistics also includes efforts of conserving meaningful cultural elements in building social relations which are verbally recorded.

Language environment in ecolinguistics includes both physical and social environments (Sapir 2001, p. 14) Within the scope of ecolinguistic studies, the living language describes, represents, depicts (represents symbolically-verbally) the reality in the environment, both physical and manmade environments (socio-cultural environment). In the socio-cultural environment, during the Dutch occupation, for example, Dutch was used as the official language of schools ranging from high school to university (Alihsjahbana 1971, p. 181). Similarly, when the Japanese invaded Indonesia, the Japanese wanted Japanese to be the official language, and even there was a ban on using Dutch language by the Japanese (Alihsjahbana 1971, p. 171). It implies that language changes as its physical and social environments change, as Liebert (cited in Mbete 2009, p. 7) states that language change represents ecological changes including changes in cultural elements. The process of change in the language runs gradually over long periods of time, unnoticed by the speaker, and unable to be be avoided.

\section{Sociolinguistics Approach}

Sociolinguistics, the study of language and its society, is concerned with the relationship between language and the context in which it is used (Holmes 2013, p. 1). In addition, sociolinguistics seeks to analyze data to make generalizations, question them and examine how they influence the language use in society (Wardaugh and Fuller 2015, p. 1-2).

As society lives in an environment, studying the relationship between language and society cannot be done without the involvement of the contextual environment. Karonese, for 
example, is both society and the language used by that society. Therefore, the language used by the Karonese society in their social interaction is the object of sociolinguistic studies. One the realization of social interaction among Karonese society is through traditional games which usually involves the surrounding physical environment as the place, the tools and the rule to play the game. The interaction between language, society and environment makes sociolinguistics and ecolinguistics good approaches to study Karonese traditional games.

\section{Ecolinguistics and Language Maintenance}

The conservation of language within the scope of ecolinguistics is inspired by Haugen's thought in which the effort of saving language is necessary because language extincts so rapidly from decade to decade (Fill, 2001, p. 44). The reason for the need to save the language is because many regional languages in this world, including Indonesian local languages, are on the critical threshold, difficult to survive, unable to show their function and fully inhereted. As a result, some local wisdom and local knowledge are being evicted and extinct. In addition, the hegemony and the dominance of several international, regional and national languages increasingly threaten the existence of minority languages (Sinar 2010, p. 70). Therefore, the study of ecolinguistics has the parameters of interrelationship (language and environment interrelation), environment (physical and social environment) and diversity (diversity of language and environment) (Haugen 2001, p. 1).

In the ecolinguistic research done by Mbete and Abdurahman (2009), two important points need to be noted. First, the number of lexicon recorded through the conceptualization process in the speaker's mind becomes a functional lexicon to use. In other words, the speakers of a language will not use lexicon that is not in their conceptual thinking. Second, the lexical conception of the speaker's mind changes in line with the changes in their physical environment. The change taking place in a long time leads to the disappearance of a number of lexicon. Even in a bilingual community, not only is there a change, but there is also a shift to another lexical conception of the more dominant language.

Responding to Mbete and Abdurahman's findings, language maintenance, the continuing use of a language in the face of competition from a regionally and socially more powerful language (Mesthrie, Swann, Deumert and Leap 2009, p. 245), is better directed to the maintenance of lexicon in a language because a change usually starts at the lexicon level.

\section{METHOD}

\section{Research Location}

The research was conducted in Lau Kambing and Turangi, two villages located in Salapian Sub-district, Stabat Region, North Sumatra Province, Indonesia.

\section{Data and Source of Data}

The data were the ecolexical items used in both the old version and the new version of cengkah-cengkah game. The data concerning the ecolexicon used in the old version were obtained from the informants, while the data concerning the ecolexicon used in the new version was obtained from the research report done by Tarigan and Sofyan (2017).

\section{Participant Characteristics}

The data were obtained from 10 informants ( 5 persons from each of the villages) selected based on the adapted criteria suggested by Samarin (1988, p. 55-70). The informants were: (i) 40 to 65 years old native speakers of Karonese domiciled in the two villages - Lau Kambing and Turangi - using Karonese language in their daily conversation; (ii) communicative; (iii) proud and eager to be informants; (iv) honest and unostracized by the surrounding community; (v) insightful and well informed about cengkah-cengkah game; and (vi) not too well-educated persons.

\section{Research Design}

This is a qualitative research for its purpose of exploring a problem and developing a detailed understanding of a central phenomenon (Creswell, 2012, p. 16), i.e. one of the Karonese traditional games, cengkah-cengkah.

\section{Data Collection}

The data were collected using interview and document. The interview carried out in this research was an unstructured, open-ended interview. In the interview, the researchers were actively involved in the dialogue by asking the participants about the status of the Karonese traditional game "cengkah-cengkah" and ecolexicon associated with it. This technique was assisted by note taking and recording techniques. The interview was audiotaped and transcribed. In addition, the document technique was carried out in this research to collect the documents related to the new version of cengkah-cengkah game.

\section{Data Analysis}

The data were analyzed using the interactive model proposed by Miles, Huberman and Saldana (2014, p. 31-33). The ecolexical items used in both old and new version of cengkah-cengkah game that have been collected were condensed to get the real data. Then, the data were displayed. Before the findings were formulated, the data had been verified. In the data verification, the researcher returned to the field twice for the purpose of not missing any useful data of this research. Then, the findings were formulated and the conclusions were drawn based on the findings.

\section{RESULTS AND DISCUSSION}

The new version of cengkah-cengkah mentioned earlier has been mainly developed or modified by involving as many items of Karonese ecolexicon as possible. Based on the data analysis, it was found that this new version of cengkah-cengkah game inserted 9 Karonese ecolexical items, i.e. bong- 
bong more (cluster fig tree), motor ben (west), motor pultak (east), njulu (south), njahe (north), buluh belangke (bamboo with long and big segments), batu (stone), batu pihpih (flat stone), and batu ricik (gravel). The insertion of such ecolexical items in the newly modified cengkah-cengkah game is intended to maintain the Karonese ecolexicon which is no longer used or even recognized by the Karonese young generation in the two villages. Besides, the findings also showed that these 9 ecolexical items were no longer recognized by people within the age of 10 to 30 years in the two villages. In terms of its rules, the new version of cengkah-cengkah keeps most of the rules used in its old version, but modifies several tools used in the game by utilizing the available natural resources in the surrounding ecosystem of the two villages.

The arena of cengkah-cengkah game shown in Figure 2 resembles a bongbong more tree (Ficus racemosa), a species of plant in the family Moraceae, popularly known as a cluster fig tree. It is a native tree throughout the tropics with a few species extending into the semi-warm temperate zone (Bailey 1953, p. 1229). In Lau Kambing and Turangi, this tree belongs to wild flora and is commonly found in the river banks; however, most of Karonese young generation do not know the Karonese word for this tree because it belongs to wild flora whose lexicon is rarely used in their daily conversations. Besides, some river banks in these two villages have been utilized by local people as the recreation place. As a result, many bongbong more trees have been cut down and replaced by buildings. Nevertheless, building a recreation place should not destruct the landscape around the river because it will destruct the local environment as well. Compared to the physical appearance of the river in the past, the river looks narrower now, and if cutting down the trees is unavoidable, the river will become narrower and narrower that eventually threatens not only the ecosystem but also the life of local people in these two villages. In fact, for the Karonese people living in these two villages, bongbong more trees are very beneficial, not for their fruits, but for their ability to prevent the soil on the edge of river from erosion (Tarigan and Sofyan 2017, p. 3). In addition to its contribution in maintaining the ecosystem in the two villages, maintaining the life of bongbong more trees also contributes to the maintenance of Karonese ecolexicon representing that tree because it will become active ecolexicon for being mentioned whenever the cengkah-cengkah game is played.

Furthermore, involving bongbong more tree in the game requires the local people in these two villages to maintain its existence. As the number of bongbong more trees in these two villages have been decreasing, people should not be allowed to cut them anymore for any purposes. In addition, more bongbong more trees should be replanted to ensure their sustainable existence in these two villages. As the trees have the capability of preventing erosion, replanting them will maintain the physical environment of the river in these two villages.

Besides, unlike the old cengkah-cengkah which did not pay attention to the cardinal points of the compass because the arena could be directed into different cardinal points, in this new version, the game is guided by such cardinal points. In Karonese language spoken in these two villages, four cardinal points - motor ben (west), motor pultak (east), njulu (south), njahe (north) - are recognized despite their relatively infrequent use in daily interactions. Based on Tarigan's (2017) findings, the ecolexicon related to cardinal points is no longer used by the age group of 10 to 30 years old Karonese living in Salapian Sub-District. Those words have been replaced by Indonesian words acquired from their formal education. If these words are not reintroduced and maintained, they will probably die and will not be recognized by the next Karonese generation. In this new version, the cengkah-cengkah arena should head west (motor ben), the cardinal point of the sunset; in other words, the game starts in the east and ends in the west, corresponding to the day cycle. In addition, understanding the four cardinal points is particularly important in fertilizing process because they determine the position of the holes into which fertilizer is inserted (Hatta 2011, p. 21).

In addition, cardinal points also play an important role in building houses. The Karonese traditional rule says that the placement of the house should head either south (njulu) or north (njahe) following the direction of the river flow in the village. Although this traditional rule is kept by the present Karonese society in these two villages, they prefer to use selatan (south) and utara (north), the Indonesian ecolexicon associated with cardinal points. From sociolinguistic perspective, their preference to use Indonesian ecolexicon shows their negative attitude towards their native language which should be converted into a pride on it. As Holmes (2013, p. 63) says that pride in our ethnic identity and our language can be important factors contributing to language maintenance.

Another Karonese ecolexicon introduced in this game is buluh belangke (Gigantochloa pruriens Widjaja), a bamboo with long and big segments. In these two villages, this kind of bamboo used to grow well in the lowlands along river banks. Due to its long and big but flexible segments, it can

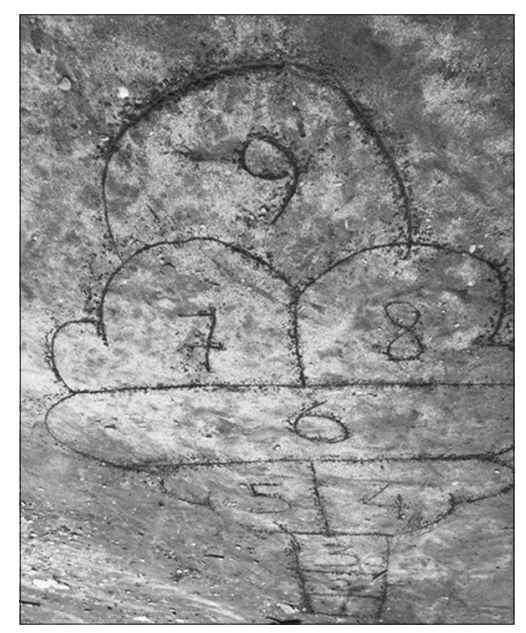

Figure 3. Using buluh belangke in drawing the cengkah-cengkah arena on the ground 
be used as a good tool to draw lines of the cengkah-ceng$k a h$ arena on the playground. The result of using buluh belangke in drawing the cengkah-cengkah arena can be seen in Figure 3.

When used as a drawing tool, the segment of the bamboo was cut into several pieces to form a stick and sharpened at its edge. As shown in Figure 3, the line is so clear and sharp that may reduce the potential of cheating during the game. In this game, a line is a boundary of each space in the game arena which must be drawn so clearly that stepping on which loses the player's turn. Buluh belangke is one of the ecolexicon associated with bamboos which is no longer recognized by the Karonese people within the age of 10 to 30 years. In fact, according to Tarigan et al. (2016), Karonese people within the age of 50 to 65 years in the villages at Salapian Sub-District recognized 10 kinds of bamboo: buluh belangke (a bamboo with long and big segments), buluh belin (a big, thick and solid bamboo), buluh cina (a bamboo as small as a pencil), buluh duri (a thorny bamboo), buluh awar (a good looking bamboo for its yellow strip), buluh kai (a yellow bamboo with green strip), buluh kayan (a bamboo with short segments), buluh kerapat (a thin bamboo with relatively long segments), buluh laga (a bamboo with straight thin segments), and buluh rires (a bamboo used to make a traditional food called rires or lemang). They also added that 4 out of the 10 kinds of bamboos were no longer recognized by the Karonese people, one of which was buluh belangke. The fact shows that if this bamboo-related ecolexicon is not reintroduced and maintained, the next generation of Karonese will never know it and will never consider its existence. By introducing buluh belangke in this game, other Karonese bamboo-related ecolexicon will possibly be frequently used resulting in its maintenance in these two vilages because other kinds of bamboo can also be used as the line marker for its replacement.

In addition to drawing better lines, buluh belangke is not costly and is easily found along the river banks in these two villages. When utilized properly, this kind of bamboo can, actually, become the living source of the local people because it can be used as the raw material to make handicraft and furniture. Setiawati, Mutaqin, Irawan, An'amillah, and Iskandar (2017) found that flexible nature of buluh belangke makes crafters easily form a wide range of household products industry. Therefore, by using this bamboo in playing cengkah-cengkah game, it gains its popularity back and is expected to be utilized by Karonese people in these two villages as their additional living source. In addition to economic benefits, buluh belangke is very helpful to the environment for its significant ability in carbon absorption (Suprihatno, Hamidy and Amin 2012, p. 91) that is useful to overcome the air pollution problem. Air pollution is not only an environmental problem faced by urban societies but it is also faced by rural societies; it even becomes a serious public health issue (Kelly and Fussell 2015). Hence, properly utilizing certain plants for economic and health purposes can also serve as one of the efforts of ecolexicon maintenance.
Besides, this new version of cengkah-cengkah uses batu (stone), an ecolexicon related to land matters. The stone is used as 'gacok', a small object leading the game. During the game, the gacok is tossed into numbered spaces ( 1 to 9 ) provided in the cengkah-cengkah arena and then the players hop or jump through the spaces to take it back. In the old cengkah-cengkah, the gacok was usually a piece of broken plate. The choice of stone as the gacok in this new version is influenced by economic factor because stone can be easily found anywhere (provided by nature) and this corresponds to the nature of traditional game which is created mainly to stimulate creative faculties of children without any costs (Snel 2009, p. 2). In addition, stone is chosen as the gacok was due to its weight. As this game is played outdoor, and the wind effect is undeniable, the gacok must be so heavy that it cannot be flown by wind.

The use of stone in this game also adds the number of Karonese ecolexicon associated with stone. The stone used in this game is gravel (batu ricik) which is flat (batu pih$p i h$ ) in order to make it easily sticked on the ground and free from wind effect. This, in turn, puts aside the use of pumice stone (batu boroh) which is too light. These ecolexical items are no longer recognized by children in these two villages because they have been replaced by Indonesian ecolexicon. By involving such kinds of stone in the game, particularly due to the important role of stone in the game, it is expected that Karonese ecolexicon associated with stones can be maintained.

Although just relying on the game to realize the Karonese ecolexicon maintenance seems impossible, it is important to be considered. Maintaining the ecolexicon of a certain object in the environment implicitly requires the local people to maintain the existence and sustainable living of that object. This is one of the contributions of ecolinguistics in saving the ecological environment and the endangered related ecolexicon.

\section{CONCLUSION}

Involving more items of Karonese ecolexicon does not only maintain the number of ecolexical items of Karonese language, but it also helps maintain the rich diversity of ecological environment in Lau Kambing and Turangi. The whole items of ecolexicon inserted into this game are those which are no longer recognized by the Karonese people within the age of 10 to 30 years; therefore, they need to be reintroduced and maintained. Despite its little contribution to language maintenance, modifying cengkah-cengkah game already shows the real effort of maintaining Karonese ecolexicon. Maintaining the ecolexicon also means maintaining the ecological environment in these two villages, or vice versa, which confirms the interdependency between language and ecology.

Despite its benefits in revitalizing the Karonese traditional game and in maintaining the Karonese ecology-related lexicon, this study has several limitations. First, this study was conducted only on one Karonese traditional game, 
i.e. cengkah-cengkah. Second, the word class of ecolexical items inserted into this new version of cengkah-cengkah game is only noun.

This is only one traditional game developed and modified for the purpose of maintaining Karonese ecolexcion, so it is suggested to other researchers to develop or modify other Karonese traditional games by inserting more ecolexicon. By introducing more ecolexical items - particularly those related to wild flora lexicon - in the traditional games, the Karonese ecolexicon would be maintained and passed to the next Karonese generation.

\section{REFERENCES}

Alisjahbana, S. T. (1971). "Some planning Processes in the Development of the Indonesian-Malay language". In J. Rubin \& B. H. Jernudd (Eds.), Can Language be Planned?: Sociolinguistic Theory and Practice for Developing Nations. Honolulu: The University Press of Hawaii.

Bailey, L. H. (1953). The Standard Cyclopedia of Horticulture. New York: The Macmillan Company.

Cardoso, H. C. (2014). (Ed.). Language Endangerment and Preservation in South Asia. Honolulu: University of Hawai'i Press.

Creswell, J. W. (2012). Educational research: Planning, conducting, and evaluating quantitative and qualitative research. $4^{\text {th }}$ Edition. Boston: Pearson.

David, M. K., Cavallaro, F., \& Coluzzi, P. (2009). Language Policies - Impact on Language Maintenance and Teaching: Focus on Malaysia, Singapore, Brunei and the Philippines. The Linguistics Journal, Special Edition on September 2009, 155-191.

Faber, P., León-Araúz, P. \& Reimerink, A. (2014). Representing environmental knowledge in EcoLexicon. In Languages for Specific Purposes in the Digital Era. Educational Linguistics, 19, 267-301.

Faber, P., León-Araúz, P. \& Reimerink, A. (2016). EcoLexicon: new features and challenges. In I. Kernerman, I. Kosem Trojina, S. Krek, \& L. Trap-Jensen. (Eds.), GLOBALEX 2016: Lexicographic Resources for Human Language Technology in conjunction with the $10^{\text {th }}$ edition of the Language Resources and Evaluation Conference, (pp. 73-80). Portorož,

Fang, T. (2017). How to Maintain a Minority Language through Education. Chinese Studies, 6, 1-11.

Fill, A. (2001). Ecolinguistics: State of the Art 1998. In A. Fill \& P. Mühlhäusler. (Eds.) The Ecolinguistics Reader. Language, Ecology and Environment (pp. 43-53). London: Continuum.

Hatta, M. (2011). Aplikasi Perlakuan Permukaan Tanah dan Jenis Bahan Organik terhadap Indeks Pertumbuhan Tanaman Cabe Rawit. Floratek, 6, 18-27.

Haugen, E. (1972). The Ecology of Language. Stanford, CA: Stanford University Press.

Holmes, J. (2013). An Introduction to Sociolinguistics. $4^{\text {th }}$ Edition. London: Routledge.
Hult, F. M. (2004). Planning for Multilingualism and Minority Language Rights in Sweden. Language Policy, 3(2), 181-201.

Kelly, F. J. \& Fussell, J. C. (2015). Air pollution and public health: emerging hazards and improved understanding of risk. Environ Geochem Health, 37(4), 631-649.

Kirkness, V. J. (2001). The Preservation and Use of Our Languages: Respecting the Natural Order of the Creator. Presented at the Barrie Area Native Advisory Circle Laguage Conference, Mnjikaning First Nation (RAMA), 23 February 2001. doi: http://dx.doi. org/10.14288/1.0103062.

Mbete, A. M. (2009). Selayang Pandang Tentang Ekolinguistik: Perspektif Kelinguistikan Yang Prospektif. Presented at The Matriculation Program at the Linguistics Master's Program of University of Udayana, Denpasar, Bali, on 12 Agustus 2009.

Mesthrie, R., Swann, J., Deumert, A., \& Leap, W. L. (2009). Introducing Sociolinguistics. $2^{\text {nd }}$ Edition. Edinburgh: Edinburgh University Press.

Miles, M. B, Huberman, A. M., \& Saldana, J. (2014). Qualitative Data Analysis: A Methods Sourcebook. $3^{\text {rd }}$ Edition. Thousand Oaks: Sage Publications.

Rosa, R. N. (2013). Introduction to Linguistics. Padang: Sukabina Press.

Sallabank, J. (2010). Language Endangerment: Problems and Solutions. eSharp, Special Issue: Communicating Change: Representing Self and Community in a Technological World, 50-87.

Samarin, W. J. (1988). Ilmu Bahasa Lapangan. Yogyakarta: Kanisius.

Sapir, E. (2001). Language and Environment. In A. Fill \& P. Mühlhäusler. (Eds.) The Ecolinguistics Reader. Language, Ecology and Environment (pp. 13-23). London: Continuum.

Setiawati, T., Mutaqin, A. Z., Irawan, B., An'amillah, A., \& Iskandar, J. (2017). Species diversity and utilization of bamboo to support life's the community of Karangwangi Village, Cidaun Sub-District of Cianjur, Indonesia. Biodiversitas, 18(1), 58-64.

Sinar, T. S. (2010). Ungkapan Verbal Etnis Melayu dalam Pemeliharaan Lingkungan. Presented at the International Seminar on Language, Literature, and Culture in Southheast Asia. Phuket Rajabhat University Thailand, 3-5 Juni 2010.

Snel, C. (2009). The role of traditional children games within the context of intangible heritage. GCAM 4: The Creative Museum: African Museums Using Culture for the Development of Children and Youth. Chief Albert Luthuli Museum, Stanger, South Africa, October 24-29, 2009, 1-5.

Suprihatno, B., Hamidy, R., \& Amin, B. (2012). Analisis Biomassa dan Cadangan Karbon Tanaman Bambu Belangke (Gigantochloa pruriens). Jurnal Ilmu Lingkungan, 6(1), 82-92.

Tarigan, B. (2017). Kebertahanan dan Ketergeseran Leksikon Flora Bahasa Karo: Kajian Ekolinguistik. A Doctoral Dissertation. Medan: Universitas Sumatera Utara. 
Tarigan, B., Setia, E. Widayati, S., \& Mbete, A. M. (2016). Language Maintenance and Shift of Flora's Lexicons in Karonese Traditional Food: An Ecolinguistic Perspective. Communication and Linguistics Studies, 2(1), 13-17.

Tarigan, B. \& Sofyan, R. (2017). Local Wisdom in the Ecolexicon Used in the New Version of Karonese Traditional Game "Cengkah-Cengkah". Presented at the $6^{\text {th }}$ International Conference on Language and Arts (ICLA), Padang, West Sumatra, Indonesia, 18-19 October 2017. Advances in Social Science, Education and Humanities Research (ASSEHR), 148, 148-152.

Wamalwa, E. W. \& Oluoch, S. B. J. (2013). Language Endangerment and Language Maintenance: Can Endan- gered Indigenous Languages of Kenya Be Electronically Preserved?. International Journal of Humanities and Social Science, 3(7), 258-266.

Wardhaugh, R. \& Fuller, J. M. (2015). An Introduction to Sociolinguistics. $7^{\text {th }}$ Edition. West Sussex: John Wiley \& Sons, Inc.

Wilczkiewicz, M. \& Wilkosz-Mamcarczyk. M. (2015). Revitalization - definition, genesis, examples. Geomatics, Landmanagement and Landscape, 2, 71-79.

Zhang, D. (2004). Home Language Maintenance among Second-Generation of Chinese American Children. Working Papers in Educational Linguistics, 19(2), 33-53. 